\title{
¿Por qué una nueva revista de investigación científica en adicciones?
}

\section{(Why a new scientific journal on addictions?)}

\author{
Roberto Tapia-Conyer ${ }^{1}$ \\ ' Editor Fundador de la RIIAD. Centros de Integración Juvenil, A.C., México
}

\section{LA RELEVANCIA DE LA INVESTIGACIÓN EN ADICCIONES A NIVEL INTERNACIONAL}

El consumo de alcohol, tabaco y drogas ilegales posee un alto impacto en la mortalidad y morbilidad de la población mundial y se encuentra entre los principales responsables tanto de mortalidad prematura como de años vividos con discapacidad en la mayoría de los países incluidos en estudios epidemiológicos internacionales (Degenhardt et al., 2008; Whiteford et al., 2013). Esta contribución del uso de sustancias a la carga mundial de enfermedad evidencia la necesidad de coordinar una respuesta internacional para contrarrestar el efecto nocivo a la salud pública.

Dicho problema se manifiesta de forma diferenciada en la población de cada país: a) en el nivel de uso de sustancias específicas (los países más desarrollados presentan un mayor consumo de alcohol y drogas ilegales), b) la capacidad del sistema de salud para tratar problemas asociados al consumo (los países con menor prevalencia de adicciones presentan recursos más limitados para su tratamiento), c) el mercado y la disponibilidad de drogas y d) los problemas biopsicosociales asociados con el consumo de sustancias (Degenhardt et al., 2008). Por lo tanto, la respuesta internacional debe descartar formular soluciones universales para el problema global del consumo de sustancias y considerar, en cambio, las diferencias entre países para aminorar su impacto en la salud pública (Becker \& Kleinman, 2013).

En este sentido, la investigación juega un papel clave que impacta significativamente en distintas dimensiones y líneas de acción como: a) el desarrollo de políticas pú-

\section{THE RELEVANCE OF ADDICTION RESEARCH AT AN INTERNATIONAL LEVEL}

Alcohol, tobacco and illicit drug use have a considerable impact on the mortality and morbidity of the global population, positioning them amongst the leading causes of early mortality and years lived with disability in most of the countries included in worldwide epidemiological studies (Degenhardt et al., 2008; Whiteford et al., 2013). The contribution of substance use to the global burden of disease supports the need for a coordinated international response to counter its harmful effect on public health.

This problem is presented in particular ways in each country population: a) levels of use of specific substances (e.g. more developed countries have higher levels of alcohol and illicit drug use), b) health system capacity to treat health problems related to substance use (e.g. countries with lower prevalence of addiction have more limited resources to treat it), c) the drug market and availability and, d) biopsychosocial problems related to substance use (Degenhardt et al., 2008). Therefore, the international response must discard the devise of universal solutions for the global issue of substance use and consider differences between countries to reduce its impact on public health (Becker \& Kleinman, 2013).

In this sense, research plays a key role and impacts many aspects and lines of action such as: a) development of substance control public policies (e.g. regulations, taxes and laws on substance distribution, use and possession), b) planning of addiction prevention and care programmes, c) delivery of specialized treatment

\section{Autor de correspondencia:}

Roberto Tapia-Conyer. Centros de Integración Juvenil, A.C. Tlaxcala núm. 208, sexto piso, col. Hipódromo, del. Cuauhtémoc, C.P. 06100, Distrito Federal, México.

DOI: 10.28931/riiad.2015.1.01 
blicas orientadas al control de sustancias (regulaciones, impuestos y leyes sobre distribución, uso y posesión), b) la planeación de programas de atención y prevención de las adicciones, c) la provisión de servicios de tratamiento especializados que empleen, en la medida de lo posible, modelos basados en evidencia científica que fundamenten su pertinencia y costo-efectividad de forma sensible al contexto específico de su implementación (Patel et al., 2008; Strang et al., 2012).

De igual manera, se esperaría que la investigación sobre las adicciones esté orientada a generar evidencia que responda a las prioridades establecidas en las políticas a nivel local, faciliten su adopción y contribuyan a una adecuada sinergia entre investigación y práctica (Strang et al., 2012). En esta línea de pensamiento, el rigor científico y la diseminación de los avances de investigación sobre adicciones adquieren una dimensión ética importante, pues además de brindar datos precisos que informen sobre las prioridades de la política pública, dan mayor certidumbre sobre el potencial beneficio de las intervenciones dirigidas a mejorar el bienestar de la población.

Es por lo anterior que se considera fundamental contar con medios de diseminación que faciliten el debate científico internacional sobre los últimos descubrimientos en el campo de las adicciones (entre ellos las determinantes biológicas y ambientales, las prevalencias en poblaciones específicas, las tendencias epidemiológicas y las comorbilidades médicas y psiquiátricas) y sobre la eficacia y la efectividad de distintos esfuerzos para su prevención y tratamiento (Rawson, Rieckmann \& Gust, 2014).

\section{¿POR QUÉ UNA NUEVA REVISTA SOBRE EL TEMA?}

Se ha documentado de manera amplia que los países en desarrollo no se encuentran adecuadamente representados en la publicación de trabajos científicos en materia de salud mental (lo que incluye al consumo de sustancias y las adicciones) (Patel \& Kim, 2007; Razzouk et al., 2010; Saxena et al., 2006; Sumathipala, Siribaddana, \& Patel, 2007). Dicha subrepresentación implica que los trabajos de investigación provenientes de estos países, con respecto a aquellos en los que tienen mayor nivel de ingresos, tienen una tasa mucho menor de aceptación para ser publicados por revistas científicas de alto impacto, así como un menor número de citas y descargas una vez que son publicados (Patel, 2007). De la misma manera, la participación de los investigadores provenientes de países de mediano y bajo ingreso cuentan con una menor representación en los comités editoriales de las publicaciones especializadas (Horton, 2003). A esta situación contribuye también el hecho de que las revistas services that adopt practices supported by scientific evidence on their pertinence and cost-effectiveness, and are sensible to the specific context of their implementation (Patel et al., 2008; Strang et al., 2012).

Likewise, it would be expected that research on addiction respond to local policy priorities, in order to facilitate adoption of an evidence-based approach, and contribute to an adequate synergy between research and practice (Strang et al., 2012). Following this line of thought, scientific rigor and dissemination of research advances on addiction acquire ethical importance, since not only they provide reliable data to inform on public policy priorities, but also bring more certainty on the potential benefit of interventions aimed at improving the well-being of the population.

Therefore, it is crucial to count with means of dissemination that facilitate the international scientific debate on the latest discoveries in addiction (e.g. biological and social determinants, its prevalence in specific populations, trends in epidemiology, and medical and psychiatric comorbidities) and on the efficacy and effectiveness of different efforts for its treatment and prevention (Rawson, Rieckmann, \& Gust, 2014).

\section{WHY A NEW JOURNAL ON THE SUBJECT?}

It has been widely documented that developing countries are not adequately represented in the publication of scientific works in mental health (which includes substance use and addiction) (Patel \& Kim, 2007; Razzouk et al., 2010; Saxena et al., 2006; Sumathipala, Siribaddana, \& Patel, 2007). This under-representation means that research articles originated from these countries, in contrast to those from countries with higher income levels, have lower acceptance rates for publication in scientific journals, and are less cited and downloaded once they are published (Patel, 2007). Likewise, researchers from low- and middle-countries have less representation in the editorial boards of specialized journals (Horton, 2003). Also contributing to this situation, is the fact that journals that are considered of "higher impact" or "scientific rigor" (which in practical terms translates into a higher number of citations and, therefore, more prestige) are edited in English; which is why it is considered an "undeniable truth" within the scientific community that writing (and publishing) texts in this language is the only way to communicate research findings, as if it is a guarantee of scientific quality (De la Portilla-Geada, 2012). This turns into a barrier for researchers born, educated and currently working in non-Anglo-Saxon countries, since it forces them to write (and therefore, think) their scientific activities in an acquired language, as well as recur to costly translation and editing services or seek a part- 
consideradas de "mayor impacto" o "rigor científico" (lo que en términos concretos se traduce en un mayor número de citas y, por tanto, mayor prestigio) son editadas en el idioma inglés, por lo que en la comunidad científica se piensa como "una verdad innegable" que publicar textos en este idioma es la única manera en la que se pueden comunicar hallazgos de investigación, como si esto fuera una garantía de calidad científica (De la Portilla-Geada, 2012). Esto supone una barrera para los investigadores nacidos, formados y que trabajan en países no anglosajones, pues los obliga a redactar (y pensar) su labor científica en un lenguaje aprendido, así como a recurrir a servicios costosos de traducción y edición de trabajos o a buscar asociaciones con autores o centros de investigación de países de habla inglesa para poder comunicar sus hallazgos de investigación. No es ninguna coincidencia que los científicos nacidos en países en desarrollo, pero radicados o educados en naciones de mayor ingreso, tengan más probabilidades de ser publicados (Alarcón, 2015).

Todo lo anterior provoca suspicacia sobre el estado actual de la ciencia y sugiere la existencia de un sesgo en los temas o enfoques de investigación de mayor interés para los países de mayor ingreso (Horton, 2003). Esto se ha denominado la "brecha 10/90 (10/90 divide)" en referencia a que $90 \%$ de la investigación publicada en salud mental proviene de menos de 20 países de mayor ingreso (Saxena et al., 2006).

Esta situación es alarmante, pues es en las naciones de menor desarrollo donde se concentra la mayor proporción de la población mundial, que es justamente la que presenta una mayor vulnerabilidad a distintos factores de riesgo asociados con las adicciones y otros trastornos de la salud mental (por ejemplo acceso limitado a servicios de salud, enfermedades insuficientemente atendidas, violencia, inseguridad, inequidad en el nivel de ingreso, desempleo y analfabetismo, entre otras) (Razzouk et al., 2010; Saxena et al., 2007). En el Plan de Salud Mental 2013-2020 de la Organización Mundial de la Salud (WHO, 2013) se reconoce como urgente la producción y diseminación de la evidencia científica local en estos contextos para hacer las intervenciones sobre adicciones más accesibles y costo efectivas, lo que contribuye al desarrollo económico de todos los países.

En el caso de Latinoamérica, se ha hecho énfasis en la necesidad de fortalecer la investigación sobre adicciones (Medina-Mora, Real, Villatoro, \& Natera, 2013), pues se considera que la investigación en salud mental en esta región posee una identidad propia que debe hacer más visibles los trabajos que tratan temas específicos, como la salud de migrantes en tránsito y población indígena, y la proliferación de centros residenciales de ayuda-mutua operados por no-profesionales, temas que nership with authors or research centres based in English-speaking countries; in order to communicate their research findings. It is no coincidence that scientists born in the developing world but based or educated in higher income countries are more likely to be published (Alarcón, 2015).

All the above brings suspicion to the current state of science, suggesting the existence of a bias in specialized publications towards topics or scientific approaches of interest to wealthy countries. This has been labelled as the "10/90 divide" in reference to the fact that 90 per cent of published research on mental health comes from less than 20 high-income countries (Saxena et al., 2006).

This situation is alarming, since it is precisely in less-developed countries where a higher percentage of the global population is concentrated, which is the one with more vulnerability to risk factors associated with addiction and other mental health disorders (e.g. violence, unemployment, under-treated physical diseases, income inequities, limited access to health services, illiteracy and insecurity) (Razzouk et al., 2010; Saxena et al., 2007). The World Health Organization's Mental Health Action Plan 2013-2020 (WHO. 2013) recognizes that the production and dissemination of local scientific evidence in these contexts is urgent, in order to make addiction interventions more accessible and cost-effective, fostering the economic development of all countries.

In the case of Latin America, emphasis has been placed on the need to strengthen addiction research (Medina-Mora, Real, Villatoro, \& Natera, 2013) since it is considered that mental health research in Latin America has an identity of its own and needs to give more visibility to scientific works that address region-specific issues such as the health of in-transit migrants, the proliferation of Mutual-Aid residential centres operated by non-professionals, the health of indigenous peoples, topics that put to test the translation of evidence-based practices in specific socio-cultural settings, such as collaborative stepped care models in rural communities (Alarcón, 2015; Patel, Chowdhari, Rahman, \& Verdeli, 2011). In spite of efforts by Latin American researchers, platforms for the dissemination of such works are limited: of the 75 scientific and medical journals, published in 18 languages, dedicated to dissemination of addiction science (International Society of Addiction Journal Editors, 2011), six publish works written in Spanish and only two are based in Latin America.

Revista Internacional de Investigación en Adicciones (RIIAD) emerges as an initiative to contribute to the closing of the gap between addiction research development and its dissemination in Latin America. This journal recognizes, from its very outset, the need to give more visibility to research conducted with high scientific 
ponen a prueba la traslación de prácticas basadas en evidencia en contextos socio-culturales distintos, como los modelos colaborativos de manejo de casos en comunidades rurales (Alarcón, 2015; Patel, Chowdhari, Rahman, \& Verdeli, 2011). A pesar de los esfuerzos de los investigadores latinoamericanos, las plataformas de diseminación para dichos trabajos son limitadas: de las 75 revistas médicas y científicas, editadas en 18 idiomas y dedicadas a la publicación de información científica sobre las adicciones (International Society of Addiction Journal Editors, 2011), seis publican trabajos de investigación en español y únicamente dos están editadas en Latinoamérica.

La Revista Internacional de Investigación en Adicciones (RIIAD) surge como una iniciativa para contribuir a cerrar la brecha entre el desarrollo de la investigación científica sobre las adicciones en Latinoamérica y su diseminación, ya que desde su concepción, reconoce la necesidad de visibilizar los trabajos conducidos con alta calidad científica provenientes de entornos distintos a los países desarrollados. Para lograrlo, la RIIAD evaluará rigurosamente la calidad científica de los trabajos publicados en cada número, independientemente de su lugar de origen, y dará espacio a textos escritos en español o inglés, para así facilitar la comunicación de la evidencia científica entre el público de distintos países. El objetivo de este esfuerzo académico es que con el paso del tiempo, la Revista se establezca como una fuente confiable de evidencia actualizada en el campo de las adicciones a nivel internacional.

Al tener el honor de presentar el primer número, extiendo una cordial invitación a investigadores de distintas disciplinas, clínicos y líderes de políticas públicas en adicciones a considerar esta publicación como una herramienta útil para informar sobre los avances y hallazgos de sus trabajos científicos.

\section{BREVE SEMBLANZA}

Roberto Tapia-Conyer es médico especialista en políticas de salud, maestro en Salud Pública y en Ciencias por la Universidad de Harvard y doctor en Ciencias de la Salud por la Universidad Nacional Autónoma de México.

Actualmente, es director general de la Fundación Carlos Slim y presidente del Patronato Nacional de Centros de Integración Juvenil. Es autor de El Manual de SaIud Pública (3ra. ed.) y del libro Las adicciones: impacto y perspectiva (2da. ed.). Diseñó e implementó el actual Sistema de Vigilancia Epidemiológica de las Adicciones en México y realizó la primera Encuesta Nacional de Adicciones en el país.

Es miembro de las Academias Nacionales de Medicina y Cirugía, así como de la Academia Mexicana de quality and originated from contexts that are dissimilar to the developed world. To achieve this, the RIIAD will rigorously assess the scientific quality of works published in each issue, regardless of their country of origin and it will also give space to publications written in Spanish and in English, in order to facilitate the communication of scientific evidence to an audience from different countries. The aim of this academic effort is to, over time, establish itself as a reliable source of up-to-date scientific evidence on addiction at an international level.

Having the honor of presenting its first issue, I extend a warm invitation to researchers from diverse disciplines, clinicians and leaders in public policy on addictions to consider this journal as a useful information tool and as an outlet to present scientific work findings.

\section{ABOUT THE AUTHOR:}

Roberto Tapia-Conyer is a medical doctor specialized in health policy, has a master's degree in Public Health and in Science from Harvard University and is a doctor in the Health Sciences by the National Autonomous University of Mexico (UNAM).

Currently, he is general director of the Carlos Slim Foundation, president of the National Board of Patrons at Centros de Integración Juvenil, A.C. He is the author of El Manual de Salud Mental (3rd. ed.) and the book Las adicciones: impacto y perspective (2nd. ed.). He designed and implemented the current Addiction Epidemiological Surveillance System in México and conducted the first National Addictions Survey.

$\mathrm{He}$ is a member of the Mexican National Academies of Medicine and Surgery, as well as the Mexican Academy of Sciences. He is a Level III researcher at the Mexican National Research System, member of the Advisory Committee of the University of California - Mexico Initiative and of the Medical and Scientific Advisory Council of the State's Employees' Social Security and Social Services Institute (ISSSTE). 
Ciencias. Es investigador Nivel III del Sistema Nacional de Investigadores, miembro del Comité Asesor de la Iniciativa de la Universidad de California con México (UC-México), y miembro del Consejo Asesor Científico y Médico del ISSSTE.

\section{REFERENCIAS}

Alarcón, R. D., (2015). El precio de la ausencia: La Psiquiatría Latinoamericana en el mundo. Salud Mental, 38(2), 81-88.

Becker, A. E., \& Kleinman, A. (2013). Mental health and the global agenda. New England Journal of Medicine, 369(1), 66-73. doi: 10.1056/NEJMra1110827

De la Portilla-Geada, N. (2012). Publicar sobre Psiquiatría:¿ en español... o en inglés?. Salud Mental, 35(6), 459-464.

Horton, R. (2003). Medical journals: evidence of bias against the diseases of poverty. The Lancet, 361(9359), 712-713. doi: http:// dx.doi.org/10.1016/S0140-6736(03)12665-7

International Society of Addiction Journal Editors. (2011). Publishing Addiction Research Internationally (PARINT). Recuperado el 24 de Agosto de 2015 de http://www.parint.org/

Medina-Mora, M. E., Real, T., Villatoro, J., \& Natera, G. (2013). Las drogas y la salud pública:¿ hacia dónde vamos?. Salud Pública de México, 55(1), 67-73.

Patel, V. (2007). Closing the 10/90 divide in global mental health research. Acta Psychiatrica Scandinavica, 115(4), 257-259. doi: 10.1111/j.1600-0447.2007.01012.x

Patel, V., Chowdhary, N., Rahman, A., \& Verdeli, H. (2011). Improving access to psychological treatments: lessons from developing countries. Behaviour Research and Therapy, 49(9), 523528. doi:10.1016/j.brat.2011.06.012

Patel, V., Garrison, P., de Jesus-Mari, J., Minas, H., Prince, M., Saxena, S., \& Advisory group of the Movement for Global Mental Health. (2008). The Lancet's series on global mental health: 1 year on. The Lancet, 372(9646), 1354-1357. doi: 10.1016/ S0140-6736(08)61556-1
Patel, V., \& Kim, Y. R. (2007). Contribution of low-and middle-income countries to research published in leading general psychiatry journals, 2002-2004. The British Journal of Psychiatry, 190(1), 77-78. doi: 10.1192/bjp.bp.106.025692

Rawson, R. A., Rieckmann, T., \& Gust, S. W. (2014). Addiction science: a rationale and tools for a public health response to drug abuse. Public Health Reviews, 35(2), 1-20.

Razzouk, D., Sharan, P., Gallo, C., Gureje, O., Lamberte, E. E., de Jesus-Mari, J., ... \& Saxena, S. (2010). Scarcity and inequity of mental health research resources in low-and-middle income countries: a global survey. Health Policy,94(3), 211-220. doi: 10.1016/j.healthpol.2009.09.009

Saxena, S., Paraje, G., Sharan, P., Karam, G., \& Sadana, R. (2006). The 10/90 divide in mental health research: trends over a 10year period. The British Journal of Psychiatry, 188(1), 81-82. doi: 10.1192/bjp.bp.105.011221

Strang, J., Babor, T., Caulkins, J., Fischer, B., Foxcroft, D., \& Humphreys, K. (2012). Drug policy and the public good: evidence for effective interventions. The Lancet, 379(9810), 71-83. doi: 10.1016/S0140-6736(11)61674-7.

Sumathipala, A., Siribaddana, S., \& Patel, V. (2004). Under-representation of developing countries in the research literature: ethical issues arising from a survey of five leading medical journals. BMC Medical Ethics, 5(1), 5-10. doi: 10.1186/14726939-5-5

World Health Organization. (2013). Mental Health Action Plan 20132020. Geneva, Switzerland: WHO Document Production Services. 